\title{
WHY TO RESEARCH ABOUT INNOVATION IS CHALLENGE?
}

\section{Editorial comment}

\author{
Angélica Pigola \\ Master student, Universidade Nove de Julho - Master's Degree in Administration \\ Priscila Rezende da Costa \\ Editor-in-Chefe \\ Isabel Cristina Scafuto \\ Coeditor \\ Marcos Rogerio Mazzieri \\ Scientific Editor
}

Cite as - American Psychological Association (APA)

Pigola, A., Costa, P. R., Mazzieri, M. R., \& Scafuto, I. C. (2021, May/Aug.). Why to research about innovation is challenge? International Journal of Innovation - IJI, São Paulo, 9(2), 215-218.

https://doi.org/10.5585/iji.v9i2.20549.

Innovativeness! Where is its place? Among several changes around the world because the pandemic of COVID-19, where would be the real place of innovation? Looking at years ago, we majority saw a technological perspective about innovation to attend demanding of business market. Today, we are sure that innovation assume and take new places socially and economically, which demanding for researchers' additional skills and abilities to follow the dynamism of this scientific field.

Researching about innovation become a challenge because it demands to put a deep effort to booster knowledge about its taxonomy, nature, definitions, mechanisms and theorical foundations. All researchers must provoke in their studies an enhancement of these basic perspectives about innovation in terms of keeping them alive or promote radical change to raise the evolution of innovation theory. Therefore, we run through these dimensions in the editorial to encourage researchers not to forget to contribute to some of these fields of innovation research. 
Taxonomy of innovation is presented in various ways in the literature. Eight different types are found including replication, redefinition, forward incrementation, advance forward incrementation, redirection, reconstruction, re-initiation, and integration (Agarwal \& Verma, 2019). This information is relevant to give us how innovation offer a tong of possibilities for scientific research beyond of technological perspectives as we are seen nowadays.

As definition, innovation would be seen like a process of interrelated activities to introduce and apply new ideas, processes, procedures, or device and systems designed to significantly benefit the individual, the group, the organization, or wider society (Cabrilo \& Grubic-Nesic, 2013; Rogers, 1995). Innovation may refer to a process in which an organization must actively develop new knowledge to solve identified problems (Nonaka, 2005) highlights that it depends heavily on knowledge (Gavrilova et al., 2018). It brings a perspective that innovation demand more than technology existence, it demands people engaged, structure available and a huge level of goodwill, cooperation and applied knowledge.

The mechanisms describe in the literature adopted a multidimensional analysis, however, to synthetize we adopt March (1991) who bring two forms of innovation mechanisms; exploitative and exploratory, which means innovation could be realized through the exploitation of existing knowledge and processes, or the exploration of new knowledge and processes (March, 1991). It means, to innovate require work with existence resources and pursue new ones when they are necessary.

Innovation is also considered crucial in solving problems of social and economic inclusion and in improving health and environmental outcomes (Porter \& Kramer, 2011; Tracey $\&$ Stott, 2017), and in this vein we highlight the main nature of innovation to assist people and enterprises to prosper in the world.

In theoretical foundation, Schumpeter's original innovation concept is indeed broad enough and encompass different sectors such as services and manufacturing (Drejer, 2004). Most innovation studies focus on technological innovation within manufacturing, reflecting that innovation theory has its roots in a time where manufacturing was still the major economic activity. A synthesis approach of service innovation appears in a sequence bringing to additional aspects of innovation (Coombs \& Miles, 2000) and more recently the social innovation has been assuming new approach towards social and economic sustainability aspects combined (Mulgan et al., 2007).

Developing innovation in the scientific field certainly requires specific talents. Taxonomy aggrandizes innovation possibilities, definitions offer likelihood to foster new 
perspectives, nature reminds that innovation is more than technology, mechanisms inform the requirements to innovate, and theoretical foundation exist to organize the history of innovation. Therefore, knowing about these perspectives can clarify how important it is to have an open and creative mind when we are expanding the history of innovation, by writing or by creating products and/or services.

Diving into this challenge of researching innovation brings in its essence a relevant vision of the alignment between science and reality, joining forces for effective advances in innovation. Going beyond current research sources, escaping academic slush, and delving deeper into knowledge in search of real advancement. So, it requires resilience, discipline, partnerships, and continuous focus.

\section{References}

Agarwal, N., \& Verma, M. (2019). A Study on Taxonomy of Innovations. Globus An International Journal of Management \& IT, 11(1), 57-64.

Cabrilo, S., \& Grubic-Nesic, L. (2013). The role of creativity, innovation, and invention in knowledge management. In Knowledge management innovations for interdisciplinary education: Organizational applications. (p. 207-232). IGI Global.

Coombs, R., \& Miles, I. (2000). Innovation, Measurement and Services: The New Problematique. In J. S. Metcalfe \& I. Miles (Orgs.), Innovation Systems in the Service Economy (Vol. 18, p. 85-103). Springer US. https://doi.org/10.1007/978-1-46154425-8_5

Drejer, I. (2004). Identifying innovation in surveys of services: A Schumpeterian perspective. Research Policy, 33(3), 551-562. https://doi.org/10.1016/j.respol.2003.07.004

Gavrilova, T., Alsufyev, A., \& Pleshkova, A. (2018). Formalizing company KM portrait: Pilot study with evidence from Russia. Measuring Business Excellence, 22(3), 315332. https://doi.org/10.1108/MBE-09-2017-0067

March, J. G. (1991). Exploration and Exploitation in Organizational Learning. Organization Science, 2(1), 71-87. https://doi.org/10.1287/orsc.2.1.71

Mulgan, G., Tucker, S., Ali, R., Sanders, B., University of Oxford, \& Skoll Centre for Social Entrepreneurship. (2007). Social innovation: What it is, why it matters and how it can be accelerated. Young Foundation.

Nonaka, I. (Org.). (2005). Knowledge management: Critical perspectives on business and management. Routledge.

Porter, M. E., \& Kramer, M. R. (2011). Criação de valor compartilhado. Harvard Business Review, 89(1/2), 62-77. 
Rogers, E. M. (1995). Lessons for Guidelines from the Diffusion of Innovations. The Joint Commission Journal on Quality Improvement, 21(7), 324-328. https://doi.org/10.1016/S1070-3241(16)30155-9

Tracey, P., \& Stott, N. (2017). Social innovation: A window on alternative ways of organizing and innovating. Innovation, 19(1), 51-60. https://doi.org/10.1080/14479338.2016.1268924 